\title{
New South American genus and species of Cleomenini (Coleoptera, Cerambycidae) ${ }^{1}$
}

\author{
Dilma Solange Napp ${ }^{2}$ \\ José Ricardo M. Mermudes ${ }^{2}$
}

\begin{abstract}
A new genus, Timabiara, and a new species, $T$. bahiensis, are described from Brazil (Bahia). The Cleomenini key for neotropical genera presented by NAPp \& MERMUDES (2001) is herein modified in order to include this new genus.

KEY WORDS. Cerambycinae, Cleomenini, new genus, South America, Timabiara
\end{abstract}

Seven South American genera represented the tribe Cleomenini Lacordaire, 1869 in the Western Hemispehere (MONNÉ 1993). Three of them have been recently revised: Haenkea Tippmann, 1953, Eupempelus Bates, 1870 (transferred to Heteropsini) and Listroptera A.-Serville, 1834 (together with Aguassay proposed as a new genus) (MERMUDES \& NAPP 2000, 2001; NAPP \& MERMUDES 2001). These studies allowed the recognition of a new genus and a new species described herein.

The specimens studied belong to the Departamento de Zoologia, Universidade Federal do Paraná, Curitiba (DZUP) and to the Museu Nacional, Universidade Federal do Rio de Janeiro, Rio de Janeiro (MNRJ).

\section{Timabiara gen. $\mathbf{n}$.}

Etymology. The name is derived from the indigenous Tupi words tymã (leg) and abyara (different, not common). It refers to the distinctive male forelegs.

Type species. Timabiara bahiensis $\mathbf{s p .} \mathbf{n}$.

Head moderately short. Frons subvertical, carinate at sides, angulate between antennal tubercles, which are prominent, acute, somewhat proximate.

Clypeus transverse, as long as half length of frons; clypeal suture rounded to angulate. Eyes finely granulate, deeply emarginate; lower lobes moderately large, not extending onto frons; upper lobes narrow, more separated than the antennal tubercles. Genae short, about $1 / 3$ as long as lower eye lobes. Mandibles somewhat enlarged, curved at apical third, acute, fringed along inner border. Apical segment of palps cylindrical, attenuate at base and apex. Ligula membranous, deeply emarginate, with well developed lateral lobes.

Antennae 10-segmented, subfiliform, shorter than body in both sexes. Scape cylindrical, enlarged, longer than segment 3 or 4 . Segment 2 about half as long as 3. Segments 3-10 slightly impressed, unarmed, neither sulcate nor carinate, 6 somewhat expanded apically. Segments 5-6 similar sized, longer than 3 or $4 ; 7$ to 9 decreasing in length; 10 about 1/3 longer than 9 , slightly appendiculate.

1) Contribuição número 1230 do Departamento de Zoologia, Universidade Federal do Paraná.

2) Departamento de Zoologia, Universidade Federal do Paraná. Caixa Postal 19020, 81531-990 Curitiba, Paraná, Brasil. Bolsista do CNPq. 
Prothorax longer than broad, subcylindrical. Pronotum somewhat convex, with a prominent, slightly acute gibbosity on each side near base. Prosternum with intercoxal process declivous, narrowed between procoxae, expanded apically. Anterior coxal cavities rounded at sides, closed behind. Mesosternum with intercoxal process subplane, wider than mesocoxa, parallel-sided, barely emarginate at apex. Intermediate coxal cavities closed to epimera. Metepisternum narrow, feebly attenuate behind. Scutellum small, quadrangular.

Elytra flattened, somewhat narrowed at middle, about 2,5-3 times the width across humeri. Each elytron with two costae; one strong, from humerus to apex, above vertical epipleuron, another prominent, straight and close to outer costa, extending from inside humeri to about middle of elytron. Epipleuron vertical, longitudinally impressed and strongly costate, the costa weakly asperate punctate, the punctures moderately dense at apical half, each with a short, stiff seta. Apices truncate, unarmed.

Legs strong, hind legs longer than twice the forelegs. Femora pedunculate, abruptly clavate at apical third, rounded at apex; clubs enlarged, peduncles deeply sulcate and bicarinate on both sides. Metafemora exceeding elytral apices in both sexes, in males by almost the club length, in females by the femoral apices. Intermediate and hind tibiae somewhat quadrangular, impressed on four sides, furrowed along inner, outer and dorsal sides. Protrochanteres, in males, each provided with a long, acute, bent projection (Fig. 2). Foretibiae, in males, expanded apically with a conspicuous inner apical projection. Tibial spurs of the hind tibiae elongate, the inner longer. First segment of metatarsi about $1 / 3$ longer than the following two combined. Tarsal pads lacking glabrous median vitta.

Abdomen suboval. First urosternite as long as the following two combined in male, longer in female, intercoxal process broad, rounded apically. Fifth urosternite rounded truncate at apex, somewhat elongate in female.

Remarks. By using the key for the neotropical Cleomenini genera given by NAPP \& MERMUDES (2001), Timabiara gen. n., stands near Haenkea Tippmann, 1953 and Dihammaphora Chevrolat, 1859. This new genus differs by having, in males, a hook-like projection on the protrochanteres and an inner apical projection on the foretibiae, in addition to the prominent, acute and somewhat proximate antennal tubercles.

Timabiara gen. n., also differenciates from Haenkea by the subfiliform, 10 -segmented antennae, short genae, round and enlarged clubs and apically rounded femora. In Haenkea the antennae are 11-segmented, with segments short and conspicuously expanded, particularly the $6^{\text {th }}$ which is pyramidal; the genae are elongate; the clubs are somewhat elongate, and the femora acutely bidentate at apex. Moreover, in the males of Hankea the sexual punctation is represented by a single, coarse, deep puncture on each side of the prosternum, which seems to be an exclusive feature of this genus (MERMUDES \& NAPP 2000, figs 4-5).

From Dihammaphora, in addition to the characters mentioned above, the new genus also differs by the strong legs, the deeply furrowed and bicarinate femoral peduncles, the conspicuously enlarged clubs, and the quadrangular, furrowed tibiae. 
The key for the neotropical genera of Cleomenini presented by NAPP \& MERMUdEs (2001) is here modified, in part, in order to include Timabiara gen. n., as follows:

1. Antennae shorter than body in both sexes. Femora abruptly clavate. Anterior coxal cavities closed behind ....................... 2a

-. Antennae longer (male) or as long as body (female). Femora gradually clavate. Anterior coxal cavities open behind $\ldots \ldots \ldots \ldots \ldots \ldots \ldots \ldots \ldots \ldots \ldots \ldots \ldots \ldots \ldots$

2a. Sixth antennal segment pyramidal, strongly expanded at apex; segments 3 to 5 and 7 to 10 short, similar in size, expanded apically. Prosternum of males with a single, coarse, deep puncture on each side at apical third. Elytra strongly asperate at sides ................. Haenkea Tippmann

-. Sixth antennal segment, at most, moderately expanded at outer apex; segments 3-5 cylindrical, 7-10 either shorter and swollen or cylindrical and longer than 3-5. Sexual punctation, if present, formed by a patch on each side of prosternum. Elytra weakly asperate at sides or not ........... $2 b$

2b. Male with protrochanteres armed with a long, acute projection and foretibiae conspicuosly expanded at inner apex. Antennal tubercles prominent, acute. Legs strong. Metafemora, in both sexes, exceeding elytral apices, in males by club length, in females by the femoral apices. Femoral peduncles deeply grooved and bicarinate, clubs enlarged. Tibiae quadrangular, sulcate along inner, outer and dorsal surfaces ............... Timabiara, gen. n.

Male lacking projection on protrochanteres, foretibiae not expanded apically. Antennal tubercles rounded, not prominent. Legs slender. Metafemora in males reaching or slightly exceeding elytral apices, shorter than body in females. Femoral peduncles shallowly grooved, clubs slender. Tibiae, at most, laterally impressed ............... Dihammaphora Chevrolat

\section{Timabiara bahiensis sp. $\mathbf{n}$.}

Figs 1, 2

Etymology. The name of the species is alusive to the type locality, Bahia.

Male. Integument black to brownish, prothorax and head reddish, frons and genae partially blackish. Frons wider than long, broadly impressed. Frons, clypeus, genae and lateral parts of head, below lower ocular eyes, densely clothed with silky, yellowish white pilosity, almost obscuring integument. Vertex opaque, with fine, shallow punctures; pilosity yellowish gold, moderately dense.

Antennae reaching apical third of elytra. Scape about 1/3 longer than segment 3 , shallowly, transversely impressed near base, densely punctocorrugate, sparsely pubescent. Segments from second, finely, shallowly punctate; pubescence whitish, denser on outer segments. Segment 3 shorter than 4, 5-6 equal-sized, as long as scape, 7 to 9 shorter than 6 and decreasing in length, 10 about $1 / 3$ longer than 9 . 
Prothorax slightly swollen at sides behind middle, then feebly attenuate to apical margin. Pronotum with a prominent, slightly acute gibbosity on each side of a shallow, subbasal impression; surface opaque, clothed with golden, more or less transversely laid pubescence, except on centro-longitudinal area, sparsely pubescent; punctation fine, shallow, denser to corrugate on disk. Sides of prothorax opaque, with pubescence and punctures similar to those of pronotum. Prosternum densely clothed with silky, yellowish pubescence, with an opaque, impunctate, glabrous patch on each side in front of coxae. Mesosternum, metasternum and urosternites densely clothed with whitish, silky, moderately long pubescence, obscuring integument.

Scutellum impunctate, glabrous. Elytra broadly subdepressed in middle at basal half, weakly asperate at sides, apices narrow, obliquely truncate. Surface densely clothed with silky, yellowish white, more or less transversely laid pubescence, obscuring integument. Costae above epipleura sparsely asperate punctate, each puncture with an erect, pale hair. Punctation, at base, coarse, dense, not seriate, the punctures becoming finer, shallower and denser apically. Epipleuron coarsely, deeply punctate, the punctures not seriate and partially obscured by pubescence.

Femoral peduncles subglabrous, with somewhat asperate, sparse punctures. Clubs sparsely whitish pubescent, with sparse, short setae. Tibiae asperate punctate, each puncture with a long, whitish hair, short pubescence lacking.

Female. Antennae slightly shorter than in male. Prosternum shallowly, finely punctate, sparsely whitish pubescent. Femoral clubs slender than in male.

Measurements, in mm, male/female: total length, 7.2-7.7/6.7-7.6; prothorax length, 1.5-1.9/1.6-1.8; prothorax width, 1.2-1.4/1.3-1.4; elytral length, 4.2-5.2/4.85.3; humeral width, 1.6-1.9/1.7-1.8.

Types. Holotype male from BRAzIL, Bahia: Encruzilhada (Motel da Divisa, Estr. Rio-Bahia, km 965, 900m), XI.1972, Seabra \& Roppa leg. (MNRJ). Paratypes: BRAZIL. Bahia: Encruzilhada (Motel da Divisa, Estr. Rio-Bahia, km 965, 900m) 1 male, 1 female, XI.1974, Seabra \& Roppa leg. (MNRJ); ibidem, 1 male, XI.1974, Seabra \& Roppa leg. (DZUP). Minas Gerais: Pedra Azul (700 m), 1 male, 1 female, XI.1972, Seabra \& Oliveira leg. (MNRJ); ibidem, 1 male, XI.1972, Seabra \& Oliveira leg. (DZUP).

Remarks. The female of T. bahiensis is similar to Dihammaphora gracicollis Chevrolat, 1859, which is known only from the holotype female, in regards to the shape and vestiture of pronotum and elytra, subfiliform antennae and in the general color. The new species differenciates, in addition to the characters mentioned in the descriptions, by the enlarged scape and the prominent dorso-lateral costa of the elytra. In Dihammaphora gracicollis the scape is slender and the dorso-lateral costa of the elytra is inconspicuous. Moreover, the antennae are 11-segmented, the legs are slender and the metafemora are conspicuously shorter than the elytra.

Figs 1-2. Timabiara bahiensis sp. n. (1) Male holotype; (2) male prosternum showing the projection on the protrochanter. 


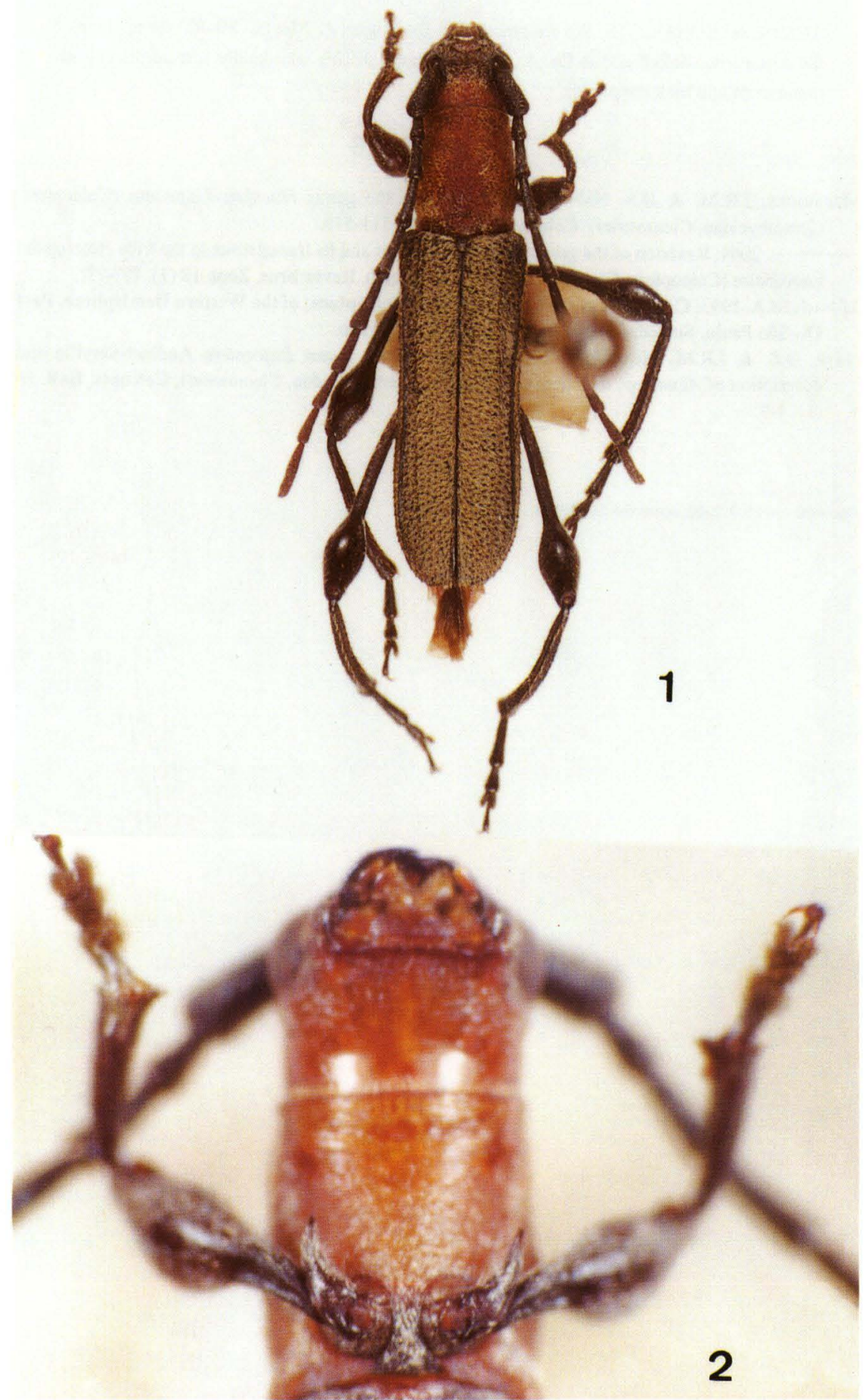

Revta bras. Zool. 18 (Supl. 1): 61 - 66, 2001 
ACKNOWLEDGMENTS. We are gratefull to Dr. Miguel A. Monné (MNRJ) for the loan of the specimens studied and to Dr. A. M. Sakakibara (DZUP) who kindly revised the english manuscript and took the photos.

\section{REFERENCES}

Mermudes, J.R.M. \& D.S. NAPP. 2000. Review of the genus Haenkea Tippmann (Coleoptera, Cerambycidae, Cleomenini). Coleopts Bull. 54 (4): 511-519.

. 2001. Revision of the genus Eupempelus Bates and its transference to the tribe Heteropsini Lacordaire (Coleoptera, Cerambycidae, Cerambycinae). Revta bras. Zool. 18 (1): ???-???.

MonNÉ, M.A. 1993. Catalogue of the Cerambycidae (Coleoptera) of the Western Hemisphere. Part IX. São Paulo, Sociedade Brasileira de Entomologia, 131p.

NAPP, D.S. \& J.R.M. MERmudes. 2001. Revision of the genus Listroptera Audinet-Serville and description of Aguassay, new genus (Coleoptera, Cerambycidae, Cleomenini). Coleopts. Bull. 55 (1): $1-9$.

Recebido em 28.IX.2000; aceito em 15.VI.2001.

Revta bras. Zool. 18 (Supl. 1): 61 - 66, 2001 